\title{
Strategi Pengembangan Model Bisnis Klaster Industri Produk Olahan Susu Cipageran
}

\author{
Development Strategy of Business Model Cluster Dairy Products Industry Cipageran
}

Nyayu Rizkita Novelia Mahgalena Lukman ${ }^{1,2^{*}}$, Rizal Syarief $^{3}$, dan Ono Suparno ${ }^{4}$

${ }^{1}$ Sekolah Bisnis, Institut Pertanian Bogor

Jl. Raya Pajajaran, Bogor 16151

${ }^{2}$ BPPT (Badan Pengkajian dan Penerapan Teknologi)

Jl. M.H.Thamrin No. 8 Jakarta Pusat

${ }^{3}$ Departemen Ilmu dan Teknologi Pangan, Fakultas Teknologi Pertanian, Institut Pertanian Bogor

${ }^{4}$ Departemen Teknologi Industri Pertanian, Fakultas Teknologi Pertanian, Institut Pertanian Bogor

Jl. Kamper Kampus IPB Darmaga, Bogor 16680, Jawa Barat

\begin{abstract}
ABSTRAK
Klaster industri produk olahan susu Cipageran Cimahi merupakan organisasi gabungan dari beberapa kelompok yang bergerak dibidang peternakan,meliputi kelompok peternak sapi perah dan kelompok pengolah susu yang dalam menjalankan tujuannya organisasi belum mampu menjalankan model bisnis dengan efektif, sehingga diperlukan strategi-strategi baru untuk memperbaiki model bisnisnya. Tujuan penelitian adalah: (1) memetakan kondisi awal model bisnis klaster industri produk olahan susu sapi Cipageran; (2) mengidentifikasikan faktor-faktor internal dan eksternal; (3) merumuskan strategi pengembangan dan perbaikan pada klaster industri produk olahan susu sapi Cipageran. Metode analisis dalam penelitian ini menggunakan kombinasi pendekatan Business Model Canvas (BMC) dan matriks Strengths, Weakness, Opportunities dan Threats (SWOT) dalam merumuskan strategi perbaikan dan pengembangan bisnis klaster industri produk olahan susu sapi Cipageran. Hasil penelitian menunjukkan perlu adanya perbaikan terhadap setiap elemen pada model bisnis klaster industri olahan susu Cipageran, Strategi perbaikan tersebut meliputi: (1) Mengembangkan infrastruktur dan jaringan teknologi informasi; (2) mengembangkan SDM dari kelompok pengolah dan peternak sapi; (3) mengembangkan budaya inovasi dengan memanfaatkan hubungan kemitraan yang kuat, jiwa dan mental wirausaha yang tinggi dan kualitas yang baik sesuai SOP yang berlaku; 4) meningkatkan nilai ekonomi pada klaster industri olahan susu sapi dalam hal kemampuan leadership dan pembuatan legalisasi kontrak antara pengolah, peternak dan konsumen.
\end{abstract}

Kata kunci: BMC, klaster industri olahan susu sapi, matriks SWOT

\begin{abstract}
The industrial cluster of dairy products Cipageran Cimahi is a joint organization of several groups engaged in animal husbandry, including dairy farmer groups and dairy processing groups that in carrying out its objectives the organization has not been able to run the business model effectively, so new strategies are needed to improve its business model . The objectives of the research are: (1) to mapping the initial condition of industrial cluster business model of Cipageran dairy products; (2) identifying internal and external factors; (3) to formulate development and improvement strategy in industrial clusters of Cipageran dairy products. The method of analysis in this study used a combination of Business Model Canvas (BMC) approach and the matrix of Strengths, Weakness, Opportunities and Threats (SWOT) in formulating the improvement strategy and business development of industrial cluster of Cipageran dairy products. The results of this study indicate that there should be improvement on each element in Cipageran dairy industry cluster business model. The improvement strategy includes: (1) Developing infrastructure and information technology network; (2) developing the human resources of
\end{abstract}

\footnotetext{
$\left.{ }^{*}\right)$ Korespondensi:

Jl. M.H.Thamrin No. 8, Jakarta 10340; email: nyayu.rizkita@gmail.com; Hp: 082111238809
} 
the cow processing and breeder groups; (3) developing innovation culture by utilizing strong partnership, soul and mentality of high entrepreneurship and good quality according to applicable SOP; 4) to increase the economic value of the dairy cattle industry clusters in terms of leadership capability and legalization of contracts between processors, breeders and consumers.

Key words: BMC, cluster processed cow milk industry, SWOT matrix

\section{PENDAHULUAN}

Susu merupakan salah satu bahan makanan yang diperlukan oleh tubuh untuk kesehatan manusia dengan kandungan gizi tinggi dan lengkap yang bersumber dari hewani. Susu segar yang dihasilkan oleh sapi perah merupakan makanan sempurna yang memiliki kandungan protein, lemak, vitamin dan mineral dalam perbandingan sempurna. Produk olahan berbasis susu ini sangat berkaitan dengan peternakan sapi perah dan kegiatan proses produksinya. Berdasarkan Agenda Pembangunan Nasional RPJMN 2015-2019 yang dicanangkan pemerintah adalah meningkatkan produktivitas rakyat dan daya saing dipasar internasional melalui peningkatan kapasitas inovasi dan teknologi. Upaya-upaya yang dilakukan pemerintah salah satunya adalah membangun 100 technopark di daerah-daerah kabupaten/kota, dan Science Park disetiap Provinsi. Sebagai bagian dari program nasional ini sesuai nawacita no. 6 yang berisi meningkatkan produktivitas rakyat dan daya saing dipasar internasional yang dicanangkan oleh Bapak Presiden Jokowi, Badan Pengkajian dan Penerapan Teknologi (BPPT) melakukan pendampingan pengembangan technopark pada beberapa daerah kabupaten/ kota, salah satunya adalah Kota Cimahi.

Kota Cimahi memiliki Klaster Industri Produk Olahan susu sapi yang berada di daerah Cipageran. Potensi pengembangan klaster industri di kota Cimahi dengan melihat lokasi industrinya, industri makanan dan minuman tersebar di tiga kecamatan di Kota Cimahi yaitu Kecamatan Cimahi Selatan, Cimahi Tengah dan Cimahi Utara. Kecamatan Cimahi Selatan memiliki 233 unit Industri Makanan Minuman jauh dibandingkan Kecamatan yang lainnya yang berada didalam wilayah Kota Cimahi. Industri produk olahan berbasis susu sapi Cipageran cukup menjanjikan apabila bisa dikembangkan seoptimal mungkin dengan koordinasi dan keterlibatan dari ke empat Pelaku dalam lingkungan klaster (Akademisi, Bisnis, Industri dan Komunitas). Pengembangan Klaster Industri yang akan diteliti pada Klaster Industri Cipageran, pada saat ini terdapat tujuh kelompok Pengolah susu yang aktif dengan enam belas produk olahan berbasis susu dan tiga kelompok peternak yang aktif dari tujuh kelompok peternak. Bappeda Kota Cimahi bulan Januari 2014 mulai menginisiasi identifikasi potensi dan penyusunan action plan pengembangan sentra susu dapi dikelurahan Cipageran dengan tujuan untuk meningkatkan taraf hidup masyarakat dibidang peternakan.

Pengembangan Ekonomi Lokal Kota Cimahi mempunyai konsep dan pendekatan yang saling berkesinambungan satu sama lainnya dimana Pemerintah Daerah bersama-sama dengan mitra lokal (Ormas, swasta, dan NGO) menciptakan lingkungan usaha yang lebih baik melalui penciptaan kondisi yang memungkinkan sektor swasta berperan dalam menumbuhkan perekonomian dan menciptakan kesempatan kerja yang dapat dinikmati oleh seluruh masyarakat. Dasar Hukum dari Pengembangan sebuah sentra adalah Peraturan Menteri Koperasi dan UMKM RI No.23 tahun 2005 yang menyatakan bahwa sentra industri adalah pusat kegiatan dengan produk unggulan sejenis. Klaster industri memiliki suatu sentra industri yang dimana didalamnya ada sektor utama, bahan baku, teknologi dan rantai nilai), syarat sebuah sentra adalah minimal terdapat 20 pelaku usaha dengan produk sejenis (Pasal 5), sebuah klaster tidak mungkin berkembang tanpa didukung sentra UKM yang kuat dan hubungan antara sentra dan klaster (Gambar 1).

Pengembangan Klaster Industri yang mencakup Pengembangan Model Bisnis Klaster Industri pada penelitian ini dengan menggunakan Bussiness Model Canvas dan membuat Matriks Strengths, Weaknesses, Opportunities dan Threats (SWOT) dalam perumusan strategi perbaikan. Menurut Awaluddin (2004), analisis SWOT dapat digunakan untuk penentuan alternatif strategi dalam penelitian yang berhubungan dengan strategi pengembangan bisnis seperti yang telah dilakukan. 


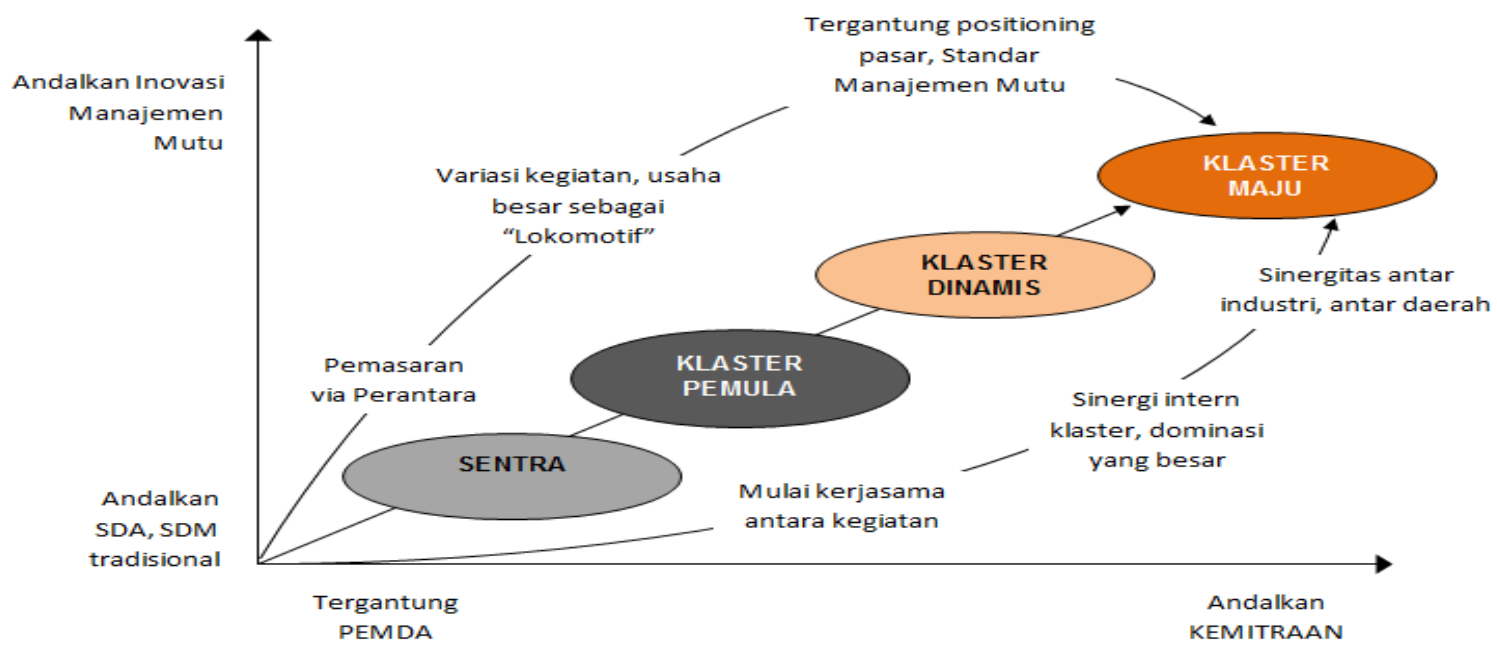

Sumber: Risfan Munir (Kemenppa).

Gambar 1. Hubungan antara sentra dan klaster industri

Hasil penelitian terdahulu dari Khusna (2015), Destiani Armunanto (2013) dan Shally Alpriany Aisyah (2013) menggunakan metode analisis SWOT dalam merumuskan alternatif strategi untuk pengembangan usaha sapi potong dimana penelitian ini membahas bahwa sangat diperlukan adanya penguatan kelembagaan peternak untuk mengatasi kebijakan impor daging dan pelatihan bagi peternak dalam hal manajemen. Klaster industri yang dipilih untuk penelitian ini adalah pengembangan klaster Industri produk olahan berbasis susu di Sentra Susu Cipageran Kota Cimahi sebagai local champion nya. Upaya Pengembangan dengan menggunakan Model bisnis ini akan berjalan efektif, jika pelaku industri mengetahui terlebih dahulu bagaimana model bisnis saat ini dijalankan dengan melakukan pemetaan Bisnis model kanvas awal, sehingga dapat dengan mudah melakukan perbaikan-perbaikan yang lebih terarah dan tepat sasaran untuk pengembangan klaster industri Produk Olahan Berbasis Susu dimasa mendatang.

Rosenfeld (1997) mendefinisikan klaster industri sebagai hasil ekonomi aglomerasi yang membawa peningkatan produktivitas sebagai akibat dari adanya konsentrasi geografi industriindustri yang saling terkait. Pengembangan Klaster secara terencana adalah inti dari peningkatan daya saing untuk keberhasilan suatu klaster. Model bisnis mencerminkan pilihan strategik dan implikasi operasional yang membantu perusahaan untuk mengkomunikasikan, menganalisis, menguji, dan memvalidasi sebuah hubungan sebab-akibat yang berasal dari pilihan strategi yang dibuat (Shafer et al., 2005). Ada beberapa tipe model bisnis yang biasanya diterapkan perusahaan untuk meningkatkan value yang dimilikinya, yaitu value networking mapping yang dikembangkan Verna Alle, model bisnis Henry Chesbrough (2010), diamond strategy yang dikembangkan Hambrick dan Fredrickson, The Four-box Business Model yang dikembangkan oleh Mark Johnson dan business model canvas yang dikembangkan oleh Osterwalder \& Pigneur (2014), semua model-model bisnis tersebut diatas Business Model Canvas (BMC) yang dikembangkan Osterwalder \& Pigneur merupakan salah satu pendekatan model bisnis yang cukup populer dan banyak digunakan oleh berbagai kalangan.

Pada penelitian yang dilakukan oleh Dwi Putri Destiani (2014), Kartika A. Silalahi (2014), dan Tikanen and Parvinen (2005), menerangkan bahwa model bisnis pada dasarnya dipengaruhi oleh aspek kognitif dan aspek materi yang telah dibangun dari suatu perusahaan dimana dalam menggunakan strategi BMC secara menyeluruh dengan menggunakan 9 unsur, yaitu customer segment, channels,customer relationships, value proposition, key activities, key resources, key partner, revenue streams dan cost structures dimana hasilnya dipergunakan untuk perbaikan dan pengembangan terhadap model bisnis perusahaan saat ini terutama pada unsur key activities, key resources, dan channel karena dianggap memiliki pengaruh besar terhadap unsur lainnya.

Model bisnis ini tidak hanya digunakan untuk perusahaan berorientasi laba namun juga untuk organisasi laba, melalui sembilan unsur yang tersusun dalam sebuah kanvas memudah- 
kan suatu klaster untuk menggambarkan model bisnis yang dijalankannya saat ini dan menampung ide-ide inovatif secara lugas dan transparan dari level manajemen, sehingga tercipta strategistrategi baru melalui perbaikan model bisnis maupun perancangan prototipe model bisnis baru. Perbaikan model bisnis dapat mengisi gap dengan menyediakan beberapa model bisnis alternatif yang dapat diuraikan dalam bentuk program-program di masa mendatang. Tujuan penelitian ini: (1) mendeskripsikan kondisi awal model bisnis klaster industri produk olahan susu sapi Cipageran; (2) mengidentifikasikan faktorfaktor internal dan eksternal; (3) merumuskan strategi pengembangan dan perbaikan pada klaster industri produk olahan susu sapi Cipageran.

\section{METODE PENELITIAN}

Penelitian ini dilakukan di BPPT-Puspiptek Serpong, Gedung Manajemen (PTKI-PKT) dan di Klaster Industri Produk Olahan Berbasis Susu di Sentra Susu Cipageran Binaan Cimahi technopark dan BPPT pada bulan Maret sampai dengan Agustus 2017. Penelitian ini dilakukan dengan metode deskriptif yang menggunakan data primer dan data sekunder. Data Primer diperoleh dari beberapa responden yang terlibat dalam kegiatan Cimahi technopark klaster industri produk olahan susu yang terdiri dari penggagas klaster industri pangan olahan (Pemerintah Cimahi dan BPPT), pakar klaster industri (akademisi dari SBM ITB, UNPAD, STIE Ekuitas), Kelompok Pengolah Susu, Kelompok Peternak dan Anggota-anggota lain yang terlibat dalam pengembangan klaster industri pangan olahan berbasis susu. Data Sekunder diperoleh melalui: Data Potensi Daerah Kota Cimahi, Data Kebijakan Daerah, Data Statistik dan hal relevan lainnya.

Teknik Pengumpulan data dan informasi pada penelitian ini dilakukan melalui: (1) Wawancara melalui komunikasi secara langsung dengan para stakeholder dalam klaster industri di Kota Cimahi; (2) Survei dan Observasi dilakukan terhadap beberapa pelaku usaha terpilih, serta stakeholder lainnya, observasi pengamatan langsung terhadap kinerja Klaster Industri di Kota Cimahi; (3) Focus Group Discussion (FGD) dan Workshop digunakan sebagai sarana pertemuan semua stakeholder yang berperan dalam pengembangan klaster industri pangan olahan di Kota Cimahi.
Penelitian ini menggunakan pendekatan business model canvas, dimana pendekatan tersebut berpedoman pada wawancara mendalam (depth interview) dan FGD yang dilakukan pada para informan/para responden dimana pertanyaannya berkaitan dengan sembilan unsur kunci yang terdapat dalam Business Model Canvas di klaster industri pangan olahan berbasis susu. Perumusan strategi menggunakan Analisis SWOT untuk melakukan pemetaan terhadap kondisi yang ada untuk diperbaiki dengan Business Model Canvas dalam menghasilkan strategi pengembangan klaster industri pangan dan olahan berbasis susu di sentra susu cipageran binaan Cimahi Technopark dan BPPT.

\section{HASIL DAN PEMBAHASAN}

\section{Pemetaan Model Bisnis dengan BMC}

Klaster industri produk olahan susu Cipageran dalam memetakan unsur-unsur model bisnisnya melibatkan pihak internal yang terdiri dari ketua klaster industri Cipageran, sekretaris, bendahara dan para anggota perwakilan dari kelompok 10 anggota dengan jumlah total 13 responden dan dipilih lima responden pakar yang mewakili masing-masing pelaku industri dengan pengetahuan yang luas mengenai pengembangan klaster industri produk olahan berbasis susu. Responden ini dipilih karena memiliki kemampuan dan kapasitas memberikan informasi rinci, akurat dan relevan terkait dengan data yang dibutuhkan untuk mengidentifikasikan masingmasing unsur BMC. Hasil dari pemetaan potret kondisi awal model bisnis Klaster Industri Cipageran dapat dilihat pada Gambar 2.

a. Customer Segment (CS)

$C S$ rantai distribusi pemasaran produk olahan susu melibatkan beberapa pelaku, yaitu Gerai Cipageran, POCI (Pojok Oleh-oleh Cimahi), koperasi, agen dan warung. Pada Sentra Susu Cipageran (Klaster Industri Cipageran). Segmen pelanggan yang dibidik adalah ibuibu rumah tangga, anak-anak sekolah dan beberapa perusahaan yang tersebar dibeberapa daerah. Dilihat dari Tipe Konsumennya, target konsumen yang diambil dan dilayani oleh klaster industri Cipageran adalah Segmented Market, dimana pasar ini melayani beberapa jenis segmen yang berbeda karakteristiknya. 


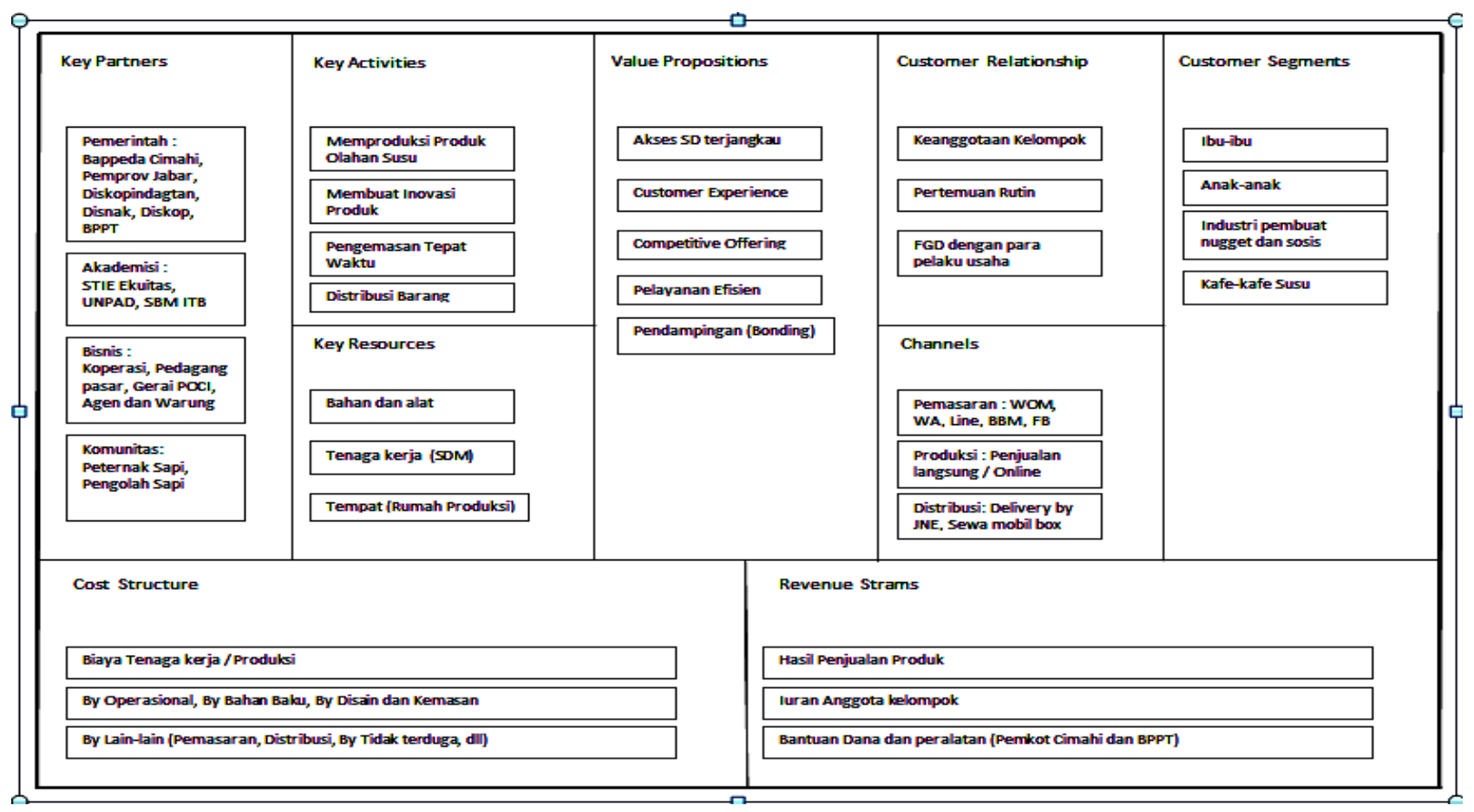

Gambar 2. Pemetaan Model Bisnis Cipageran saat ini

\section{b. Value Proposition (VP)}

$V P$ Klaster Industri Cipageran saat ini menawarkan beberapa proposisi nilai bagi Kelompok Peternak dan Pengolah Susu di Sentra Susu Cipageran, antara lain: bonding, bidging dan networking. Bonding yang ditawarkan oleh klaster ini berupaya memajukan kelompok peternak dan kelompok pengolah susu untuk menjadi kelompok yang bersinergi dengan baik melalui proses pendampingan ilmu pengetahuan, bridging klaster ini membangun kolaborasi pihak-pihak yang terlibat didalamnya untuk mengembangkan ekonomi lokal.

c. Channels $(\mathrm{CH})$

$\mathrm{CH}$ dalam mengkomunikasikan $V P$ kepada pelanggannya Klaster Industri Cipageran menggunakan metode WOM (menyampaikannya informasi dari mulut ke mulut) serta menggunakan layanan telepon, sms dan sosmed, penjualan produk bisa langsung dan bisa secara online, delivery bisa melalui JNE atau sewa mobil.

d. Customer Relatonship (CS)

CS yang dibangun oleh Klaster Industri Cipageran dengan pelanggannya adalah personal assistance dimana pelanggan berkomunikasi secara langsung dengan pihak pengelola Klaster Industri Cipageran dan dedicated personal assistance Pelanggan dilayani secara khusus oleh pihak pengelola Klaster Industri Cipagerannya dan bila pelanggan berkenan bisa diajak ke rumah produksi olahannya dan peternakan sapinya, agar bisa melihat langsung proses produk yang akan dijual, communities (pemilik usaha/owners membuat group di LINE, WA dan BBM untuk menjalin hubungan dengan komunitas pelanggannya). Hubungan yang dibina dalam Klaster Industri Cipageran menyampaikan VP melalui pertemuan rutin dan pendampingan, baik konsep, praktek maupun forum diskusi mengenai peternakan dan pengolahan susu.

e. Revenue Streams (RS)

$R S$ Klaster Industri Cipageran bersumber dari penjualan produk baik pendapatan dari beli putus (biaya berlangganan) dan bantuan dari pemerintah daerah dan juga bantuan peralatan dari BPPT dan stakeholder lainnya. Selain itu dalam melakukan aktivitas produksi Klaster Industri Cipageran mendapatkan sumber pendanaan yang berasal dari iuran para anggota kelompok.

f. Key Resources (KR)

$K R$ klaster industri produk olahan susu Cipageran terbagi atas sumber daya fisik seperti: bahan, alat dan rumah produksi, sumber daya manusia terdiri atas tenaga kerja dan kekayaan intelektual pegawainya dalam memiliki kemampuan untuk membuat inovasi produk. Dalam melakukan proses produksi tidak ada pembagian yang spesifik diantara anggota kelompok semua pekerjaan yang dilakukan secara bersama-sama. 
g. Key Activies (KA)

$K A$ dalam menjalankan usahanya Klaster Industri Cipageran ada beberapa kegiatankegiatan utama Klaster Industri Cipageran agar model bisnisnya dapat berjalan berdasarkan hasil wawancara dan pendekatan rantai nilai proses ada dua kegiatan utama meliputi aktivitas primer dan aktivitas pendukung dalam memproduksi olahan susu, membuat inovasi produk, melakukan pengemasan barang dan mendistribusikan barang tepat waktu.

h. Key Partnerships (KP)

$K P$ Didalam pengembangan klaster industri pangan olahan berbasis susu tidak terlepas dari peran berbagai mitra yang mendorong jalannya model bisnis. Saat ini Klaster Industri Cipageran menjalin kemitraan yang kuat dengan Bappeda Kota Cimahi, Diskopindagtan Kota Cimahi, Kelurahan Cipageran, Fapet Unpad, FTIP Unpad, STIE Ekuitas dan Tokoh Masyarakat. i. Cost Structures (CS)

CS Klaster Industri Cipageran didalam menjalankan model bisnisnya tidak terlepas dari biaya-biaya yang dikeluarkan saat mengoperasikan model bisnis. Struktur biaya sangat bergantung dari pengelolaan terhadap sumber daya utama (key resources), kegiatankegiatan utama yang dimiliki organisasi (key activities) dan kemitraan yang dibangun untuk memudahkan model bisnis berjalan (key partnerships). Struktur biaya dari kegiatan usaha Sentra Susu Cipageran, meliputi:

- Biaya Tenaga kerja per produksi

- Biaya Operasional Peralatan yang terdiri dari listrik, bahan bakar dan transportasi

- Biaya Bahan baku

- Biaya Lain-lain (Biaya Pemasaran, Distribusi, Biaya Tak Terduga dll)

- Biaya Desain dan Kemasan

Tabel 1. Analisis SWOT pada klaster industri produk olahan susu Cipageran

\begin{tabular}{|c|c|c|c|c|}
\hline Unsur & Kekuatan & Kelemahan & Peluang & Ancaman \\
\hline $\begin{array}{l}\text { Customer } \\
\text { Segments }\end{array}$ & $\begin{array}{l}\text { Pelanggannya ibu-ibu, } \\
\text { anak-anak dan industri } \\
\text { makanan olahan }\end{array}$ & $\begin{array}{l}\text { Belum tersosialisasikan } \\
\text { mengenai produk olahan } \\
\text { susu kepada konsumen }\end{array}$ & $\begin{array}{l}\text { Membuat kawasan } \\
\text { Edufarm untuk } \\
\text { para Pelanggan }\end{array}$ & $\begin{array}{l}\text { Persepsi masyarakat yang } \\
\text { salah mengenai produk } \\
\text { olahan susu sapi }\end{array}$ \\
\hline $\begin{array}{l}\text { Value } \\
\text { Proposition }\end{array}$ & $\begin{array}{l}\text { Pendampingan dengan } \\
\text { ABGC, Bantuan CSR } \\
\text { Bank Jabar Banten dan } \\
\text { PT.Cargill }\end{array}$ & $\begin{array}{l}\text { Perijinan } I M D \text { dan } I R T \\
\text { terhambat karena } \\
\text { persyaratan }\end{array}$ & $\begin{array}{l}\text { Memperluas } \\
\text { Networking dengan } \\
\text { menjalin mitra- } \\
\text { mitra strategis }\end{array}$ & $\begin{array}{l}\text { Kendala jarak,waktu dan } \\
\text { biaya meningkatkan cost. }\end{array}$ \\
\hline Channels & $\begin{array}{l}\text { Komunikasi secara } \\
\text { langsung dan dua arah } \\
\text { dengan pelaku usaha }\end{array}$ & $\begin{array}{l}\text { Koordinasi Manajemen } \\
\text { dan penggunakan } \\
\text { Teknologi }\end{array}$ & $\begin{array}{l}\text { Memanfaatkan } \\
\text { sosmed untuk } \\
\text { menarik minat } \\
\text { pelanggan } \\
\end{array}$ & $\begin{array}{l}\text { Banyak Pesaing yang } \\
\text { mencari keuntungan } \\
\text { sebesar-besarnya }\end{array}$ \\
\hline $\begin{array}{l}\text { Customer } \\
\text { Relationships }\end{array}$ & $\begin{array}{l}\text { Memiliki hubungan } \\
\text { kuat dengan pelanggan }\end{array}$ & $\begin{array}{l}\text { Kontrak Kerjasama belum } \\
\text { ada (hanya asas } \\
\text { kepercayaan) }\end{array}$ & $\begin{array}{l}\text { Penjualan Langsung } \\
\text { dan Penjualan } \\
\text { Online }\end{array}$ & $\begin{array}{l}\text { Penawaran yang lebih } \\
\text { menarik dari Pesaing }\end{array}$ \\
\hline $\begin{array}{l}\text { Revenue } \\
\text { Streams }\end{array}$ & $\begin{array}{l}\text { Penjualan Langsung dan } \\
\text { Penjualan Online dan } \\
\text { iuran dari anggota } \\
\text { koperasi }\end{array}$ & $\begin{array}{l}\text { Gerai mengambil } \\
\text { keuntungan } 20 \% \text { dari } \\
\text { kelompok dan dibayarkan } \\
\text { dua minggu sekali }\end{array}$ & $\begin{array}{l}\text { Inovasi Produk dan } \\
\text { mengembangkan } \\
\text { Pemasaran }\end{array}$ & $\begin{array}{l}\text { Iklim persaingan bisnis } \\
\text { masing-masing kelompok } \\
\text { mencantumkan harga } \\
\text { yang berbeda-beda }\end{array}$ \\
\hline Key Resources & $\begin{array}{l}\text { SDM: Pendampingan } \\
\text { dari SMD WP dan } \\
\text { ABGC Teknologi: } \\
\text { Medsos Infrastruktur: } \\
\text { bantuan dari CSR }\end{array}$ & $\begin{array}{l}\text { Sumber Daya Fisik masih } \\
\text { Minim, maka perlu } \\
\text { adanya penambahan yang } \\
\text { menunjang proses } \\
\text { produksi }\end{array}$ & $\begin{array}{l}\text { Sumber Daya Alam } \\
\text { berlimpah dan bisa } \\
\text { dimanfaatkan } \\
\text { sebaik-baiknya }\end{array}$ & $\begin{array}{l}\text { ketersediaan alat Produksi } \\
\text { mempengaruhi mutu } \\
\text { pasokan produk susu }\end{array}$ \\
\hline Key Activities & $\begin{array}{l}\text { Proses Produksi, Inovasi } \\
\text { Produk, Pengemasan } \\
\text { dan Pengiriman efisien }\end{array}$ & $\begin{array}{l}\text { Kel.Peternak dan } \\
\text { Kel.Pengolah susu masih } \\
\text { berdiri sendiri-sendiri }\end{array}$ & $\begin{array}{l}\text { Perlu dibuat Sistem } \\
\text { Manajemen yang } \\
\text { bisa mengatur } \\
\text { aktivitas utama } \\
\end{array}$ & $\begin{array}{l}\text { Persaingan bisnis antara } \\
\text { masing-masing kelompok } \\
\text { dan tengkulak } \\
\text { mendominasi pemasaran }\end{array}$ \\
\hline $\begin{array}{l}\text { Key } \\
\text { Partnerships }\end{array}$ & $\begin{array}{l}\text { Fokus pada kerjasama } \\
\text { dengan para pelaku } \\
\text { usaha }\end{array}$ & $\begin{array}{l}\text { Belum dibuat legalisasi } \\
\text { kontrak kerjasama }\end{array}$ & $\begin{array}{l}\text { Membentuk } \\
\text { Koperasi agar } \\
\text { terintegrasi satu } \\
\text { sama lainnya } \\
\end{array}$ & $\begin{array}{l}\text { kelompok satu persatu } \\
\text { mengundurkan diri }\end{array}$ \\
\hline Cost Structure & $\begin{array}{l}\text { Biaya Operasional } \\
\text { efisien dan biaya lain- } \\
\text { lain dapat diprediksi }\end{array}$ & $\begin{array}{l}\text { Biaya Bahan Baku tinggi, } \\
\text { harga penjualan tidak } \\
\text { sesuai }\end{array}$ & $\begin{array}{l}\text { Meningkatkan } \\
\text { Teknologi } \\
\text { Peternakan dan } \\
\text { Pengolahan Susu }\end{array}$ & $\begin{array}{l}\text { Pengaruh musim } \\
\text { menaikkan harga bahan } \\
\text { baku pakan }\end{array}$ \\
\hline
\end{tabular}




\section{Analisis SWOT terhadap BMC}

Setelah melakukan identifikasi pemetaan terhadap sembilan unsur model bisnis kanvas pada klaster industri Cipageran, tahapan selanjutnya melakukan analisis SWOT. Analisis SWOT bertujuan menganalisis kondisi internal dan eksternal pada klaster industri Cipageran. Hasil analisis SWOT dapat digunakan untuk memperbaiki model bisnis kanvas yang telah ada. Berdasarkan hasil FGD, observasi, wawancara dan kuesioner dengan para responden, maka analisis SWOT pada sembilan unsur kanvas model bisnis klaster industri Cipageran pada Tabel 1.

\section{Perumusan Strategi Perbaikan melalui Matriks SWOT}

Dari hasil Pemetaan SWOT kondisi saat ini terdiri dari sembilan unsur selanjutnya dipilih beberapa faktor yang menjadi isu strategis dalam pengembangan model bisnis klaster industri produk olahan susu Cipageran (Sensucip), Isu-isu strategik ini diperoleh berdasarkan hasil wawancara (depth interview), FGD dan pengamatan secara langsung terhadap kondisi organisasi saat ini dilihat dari kondisi faktor, struktur persaingan dan strategi perusahaan, industri pemasok, terkait dan inti, pembeli (konsumen). Hasil analisis tersebut dirumuskan menjadi beberapa strategi seperti yang tercantum pada Tabel 2.

Analisis matriks SWOT Klaster Industri Produk Olahan Susu Cipageran menghasilkan empat Strategi yang bisa digunakan oleh Sentra Susu Cipageran (Sensucip) dalam mengembangkan produk olahannya berbasis susu, strategi pengembangan klaster industri ini dirumuskan berdasarkan hasil pemetaan model bisnis klaster, Analisis SWOT dari setiap unsur BMC dan juga dirumuskan berdasarkan pendekatan partisipatif melalui diskusi (FGD) yang melibatkan berbagai komponen klaster industri. Strategi pengembangan klaster industri ini dirumuskan berdasarkan hasil pemetaan model bisnis klaster, Analisis SWOT dari setiap unsur BMC dan juga dirumuskan berdasarkan pendekatan partisipatif melalui diskusi (FGD) yang melibatkan berbagai komponen klaster industri, strategi pengembangan klaster industri yang dihasilkan dari analisis matriks SWOT diantaranya:

Tabel 2. Matriks SWOT klaster industri produk olahan susu Cipageran

\begin{tabular}{|c|c|c|}
\hline Faktor Eksternal & $\begin{array}{l}\text { Strengths }-S \\
\text { 1. infrastruktur memadai } \\
\text { 2. Tersedianya Pelaku industri untuk } \\
\text { melakukan produksi } \\
\text { 3. Adanya Gerai Sentra Susu (Tempat } \\
\text { penjualan) } \\
\text { 4. Bahan Baku Berlimpah } \\
\text { 5. Dukungan dari Pemkot Cimahi } \\
\text { 6. Permintaan Susu Segar Meningkat } \\
\text { 7. Permintaan Yoghurt dalam bentuk } \\
\text { Plain meningkat untuk restoran }\end{array}$ & $\begin{array}{l}\text { Weaknesses - } W \\
\text { 1. Adanya ikatan kontrak tidak tertulis } \\
\text { antara peternak dan industri } \\
\text { pengumpul susu } \\
\text { 2. Mutu Produk dan Kualitas Kemasan } \\
\text { masih kurang baik (rasa berubah- } \\
\text { ubah) } \\
\text { 3. Ketergantungan dari kelompok } \\
\text { olahan susu } \\
\text { 4. Kurangnya motivasi sebagai } \\
\text { wirausaha } \\
\text { 5. Proses produksi, pemasaran dan } \\
\text { inovasi tidak maksimal }\end{array}$ \\
\hline $\begin{array}{l}\text { Opportunities - } \mathrm{O} \\
\text { 1. Para pihak tertarik untuk } \\
\text { mengembangkan klaster susu } \\
\text { 2. Teknologi dan Informasi } \\
\text { berkembang } \\
\text { 3. Mitra memperluas jaringan } \\
\text { kerjasama } \\
\text { 4. Persaingan masih sedikit } \\
\text { 5. Pembeli/Konsumen sudah } \\
\text { menyadari cinta produk lokal } \\
\text { 6. Tidak memiliki izin usaha }\end{array}$ & $\begin{array}{l}\text { S-O Strategy } \\
\text { Mengembangkan Infrastruktur dan } \\
\text { Jaringan Teknologi Informasi } \\
(\mathrm{S} 1, \mathrm{~S} 2, \mathrm{~S} 3, \mathrm{~S} 5, \mathrm{~S} 6, \mathrm{~S} 7, \mathrm{O} 1, \mathrm{O} 2,03,04, \mathrm{O} 6)\end{array}$ & $\begin{array}{l}\text { W-O Strategy } \\
\text { Mengembangkan SDM dari Kelompok } \\
\text { Pengolah dan Peternak Sapi } \\
(\mathrm{W} 2, \mathrm{~W} 3, \mathrm{~W} 4, \mathrm{O} 1, \mathrm{O} 2, \mathrm{O} 3)\end{array}$ \\
\hline $\begin{array}{l}\text { Threats - T } \\
\text { 1. Dukungan Kerjasama dengan } \\
\text { ABGC Berbatas waktu } \\
\text { 2. Jiwa dan mental wirausaha masih } \\
\text { lemah } \\
\text { 3. Kualitas bahan mentah (susu } \\
\text { murni) tidak sama, } \\
\text { 4. Lokasi industri pendukung dan } \\
\text { Penjual bahan pendukung cukup } \\
\text { jauh dari Cipageran }\end{array}$ & $\begin{array}{l}\text { S-T Strategy } \\
\text { Mengembangan Budaya Inovasi dengan } \\
\text { cara memanfaatkan hubungan kemitraan } \\
\text { yang kuat dengan jiwa dan mental } \\
\text { wirausaha anggota kelompoknya diikuti } \\
\text { dengan meningkatkan mutu sesuai SOP } \\
\text { yang berlaku(S1,S2,S4,S5,T1,T3) }\end{array}$ & $\begin{array}{l}\text { W-T Strategy } \\
\text { Meningkatan nilai ekonomi industri } \\
\text { produk olahan susu sapi dengan } \\
\text { meningkatkan kemampuan leadership } \\
\text { manajemen dan pengetahuan peternak } \\
\text { dalam menggunakan teknologi } \\
\text { informasi dan komunikasi dan membuat } \\
\text { ikatan kontrak tertulis dan memiliki izin } \\
\text { usaha. (W1,W2,W4,W5,W6,T1,T3,T4) }\end{array}$ \\
\hline
\end{tabular}




\section{S-O Strategy}

Mengembangkan infrastruktur dan jaringan teknologi informasi dengan melakukan beberapa program-program dalam pengembangan klaster industri. Dalam pengembangan infrastruktur dan jaringan teknologi informasi (TI) dalam klaster industri produk olahan Cipageran memerlukan hal berikut:

a. Pengembangan rumah produksi dengan mensosialisasikan standar rumah produksi pengolahan produk susu yang baik beserta perbaikan rumah produksi misalnya: menyediakan partisi yang memisahkan antara rumah produksi dan rumah tinggal, membangun rumah produksi sesuai standar dam menyediakan desain rumah produksi.

b. Penyelesaian masalah perizinan dengan memfasilitasi pelatihan perusahaan industri rumah tangga (PIRT), yaitu bagaimana cara mengolah pangan dengan baik dan mendampingi dan membantu permasalahan pengajuan permohonan izin usaha.

c. Memperbaiki sektor dari hulu dalam mengembangkan usaha peternakan dan kesehatan sapi dengan melihat standar kandang sapi yang baik, menyediakan pakan sapi yang sehat dan bermutu baik dan mengerti cara penanggulangan penyakit hewan.

d. Perbaikan sarana dan prasarana penunjang industri produk olahan susu sapi, misalnya: perbaikan dan pelebaran jalan produksi, pengadaan instalasi artesis, peningkatan fasilitas listrik, penambahan transportasi umum dan pembangunan gapura/penanda sentra kelompok Cipageran.

e. Meningkatkan kerjasama untuk berkolaborasi dengan industri, lembaga penelitian dan pemerintah pusat/kota dengan cara mendorong program Corporate Social Responsibility (CSR) yang mendukung pengembangan usaha produk olahan susu sapi, memfasilitasi studi banding ke industri susu dan pengolahan produk olahan susu, melakukan kerjasama dengan berbagai lembaga penelitian, memfasilitasi program rutin gerakan gemar minum susu dilingkungan pemerintah, pendidikan dan masyarakat lokal, memfasilitasi kerjasama masalah perizinan dan bantuan pemerintah provinsi terkait lahan produksi.

\section{Strategi $\mathrm{W}-\mathrm{O}$}

Mengembangkan SDM dari kelompok pengolah dan peternak sapi dengan membentuk
Koperasi Peternak Susu agar tidak adanya ketergantungan dari kelompok-kelompok olahan susu terhadap gerai dalam segi pemasaran. Pengembangan SDM memerlukan pelatihan, baik pelatihan breeding/budidaya, pelatihan pakan ternak yang berkualitas, pelatihan manajemen kandang dan pelatihan kesehatan ternak.

\section{Strategi S-T}

Mengembangkan budaya inovasi dengan cara memanfaatkan hubungan kemitraan yang kuat dengan jiwa dan mental wirausaha anggota kelompoknya diikuti dengan meningkatnya mutu sesuai Standard Operating Procedure (SOP) yang berlaku.

\section{Strategi W-T}

Meningkatan nilai ekonomi industri produk olahan susu sapi dengan meningkatkan kemampuan leadership manajemen dan pengetahuan peternak dalam menggunakan TI dan komunikasi melalui pelatihan,pameran, percontohan, forum komunikasi dengan komunitas dan para pelaku usaha dan membuat ikatan kontrak tertulis dan memiliki izin usaha yang memberikan rasa nyaman bagi peternak dan pengumpul susu. Strategi ini merupakan usaha meningkatkan nilai ekonomi melakukan pengembangan model bisnis dengan melakukan pendampingan pengelolaan bisnis (peningkatan mutu produk, kemasan, manajemen dll), pendampingan pengembangan kemitraan usaha dengan lembaga keuangan dan CSR, melakukan legalisasi kerjasama dengan kelompok peternak untuk memasok susu, melakukan legalisasi kerjasama dengan industri kemitraan usaha (minimarket, POCI, Kafe dan Restoran), melakukan legalisasi kerjasama dengan industri kemitraan usaha untuk peningkatan kemampuan teknologi industri.

\section{Perbaikan Model Bisnis Klaster Industri Produk olahan Susu Cipageran}

Perbaikan model bisnis perubahannya sangat penting untuk dapat menilai keberhasilan suatu perusahaan dan memungkinkan perusahaan untuk dapat beradaptasi dengan perubahan dipasar maupun lingkungan yang penuh persaingan (kompetitif). internal sehingga menghasilkan keuntungan kompetensi bagi perusahaan kecil. Menurut Geisen et al., (2010) ada beberapa unsur atau komponen yang sebaiknya ada didalam model bisnis, yaitu dengan memperbaiki yang ada, yaitu: 
a. Nilai yang dikirimkan ke;pada pelanggan: customer segments, the value proposition, the spesific"job to be done", what is sold and what to be sold

b. Bagaimana cara nilai tersebut sampai kepada pelanggan: critical internal resources and processess as well as internal partnership

c. Bagaimana mengumpulkan pendapatan: the pricing model and form of monetization

d. Bagaimana posisi perusahaan diantara industri lainnya: the company's role and relationships across the value chain.

Pengembangan organisasi berupaya melakukan perbaikan pada unsur-unsur yang menjadi kelemahan organisasi, sehingga organisasi dapat ditingkatkan dan membangun organisasi internal perusahaan (Casadesus dan Ricart, 2010). Perumusan model bisnis perbaikan yang dihasilkan analisis matriks SWOT memuat empat strategi perbaikan. Hasil perbaikan model bisnis dari klaster industri olahan susu Cipageran berdasarkan pertimbangan dari hasil SWOT yang telah dilakukan sebelumnya, yaitu:

a. $C S$

Perbaikan dari segmen pelanggan ini adalah Klaster industri olahan susu Cipageran yang berada pada kondisi awal membidik ibu-ibu, anak-anak, industri pembuat nugget/sosis, kafe-kafe susu sebagai kekuatan setelah dievaluasi dengan SWOT pada segmen pelanggan melalui hasil FGD dan wawancara langsung dengan ketua Sensucip diperoleh hasil analisis menambahkan segmen pelanggan di sekolahsekolah/PTS/PTN dan Instansi pemerintah/ swasta, pebisnis/investor.

b. VP

Proposisi Nilai yang ditawarkan klaster industri produk olahan susu Cipageran kepada para pelanggannya adalah: Akses sumber daya yang terjangkau, customer experience, competitive offering, efisiensi dibidang pelayanan, bonding (pendampingan ABGC) dan Bridging (menjembatani antara peternak dan pengolah). Dalam pelaksanaannya belum bisa terlaksana dengan baik, dikarena membutuhkan visi yang sama dalam menerapkan $V P$, perbaikannya model bisnis dalam segmen proposisi nilai ini lebih ke upaya memperluas networking peternak dan pengolah, networking membangun jaringan kerjasama antara pihak internal dan pihak eksternal agar tujuan mendapatkan mitra-mitra strategik didalam pengembangan bisnis klaster bisa terlaksana dengan baik. c. $\mathrm{CH}$

Perbaikan model bisnis pada segmen $\mathrm{CH}$ lebih ke membuat aplikasi berbasis internet yang sistemnya terintegrasi satu sama lain dengan kelompok pengolah, peternak maupun pelanggan.

d. $C R$

Perbaikan model bisnis pada segmen $C R$ berkaitan dengan kebutuhan ikatan kontrak tertulis dan memiliki izin usaha, sehingga bisa memberikan rasa nyaman kepada pelanggan dan sering mengadakan temu bisnis dengan para pelanggan dengan adanya outbound bersama pelanggan untuk pengembangan SDM dan memmbuat Buku Panduan Operasional Produk agar pelanggan bisa lebih mengetahui produk olahan apa saja yang dihasilkan oleh Cipageran.

e. $R S$

Perbaikan model bisnis dari aliran pendapatan ini lebih ke pengembangan budaya inovasi dengan cara memanfaatkan hubungan kemitraan yang kuat dengan jiwa dan mental wirausaha berani untuk menghadapi iklim persaingan dari masing-masing kelompok untuk menetapkan harga produk berbedabeda, memanfaatkan hubungan kemitraan dapat dilakukan dengan mengadakan jasa pelatihan dan menjadi narasumber dengan mendapatkan honor untuk dijadikan income dari Sensucip, jasa periklanan dari web Sensucip yang dikelola oleh manajemennya.

f. $K R$

$K R$ dari Sensusip ini dimulai dari pengadaan bahan, peralatan, pegawai (SDM), tempat (rumah produksi), sumber daya utama dari Sensucip kekuatannya ada pendampingan dari SMD WP dan ABGC, Teknologi Medsos, infrastrukturnya (bantuan dari CSR), disamping kekuatan ada beberapa kelemahan yang ditemui yaitu sumber daya fisik masih minim perlu adanya penambahan yang menunjang proses produksi sehingga bisa memengaruhi mutu pasokan produk susu oleh karena itu dibuatlah strategi perbaikan dalam mengembangkan infrastruktur dan jaringan teknologi informasi dengan membuat suatu aplikasi sistem yang terintegrasi.

g. $K A$

Aktivitas utama yang dijalankan oleh Sensucip di dalam klaster industri produk olahan susu Cipageran dimulai dari memproduksi produk olahan berbasis susu, membuat inovasi 
produk, pengemasan produk tepat waktu dan segmentasi pasar. aktivitas utama ini kelompok peternak dan kelompok pengolah susu masih berdiri sendiri-sendiri, sehingga berpeluang untuk membuat sistem manajemen yang bisa mengatur aktivitas utama, pengawasan dari aktivitas utama perlu ditingkatkan untuk menghindari dari persaingan bisnis antara masing-masing kelompok dan tengkulak yang mendominasi pemasaran. Dalam hal ini strategi perbaikannya perlu adanya pelatihan dan sosialisasi yang berkaitan dengan aktivitas dari hulu sampai ke hilir.

h. $K P$

Kerjasama dengan mitra-mitra memberikan peluang pada segmen $K P$ melakukan perbaikan dalam hal mengembangkan budaya inovasi dengan cara memanfaatkan hubungan kemitraan yang kuat dengan jiwa dan mental wirausaha, serta perlu adanya penambahan kemitraan dengan perusahaan kemasan,agar kemasan lebih menarik, unik dan memiliki nilai jual yang tinggi.

i. $C S$

Klaster industri produk olahan susu Cipageran berusaha mengefisienkan biaya operasional dan biaya lain-lain yang dapat diprediksi, tetapi memiliki kelemahan pada biaya bahan baku tinggi, sehingga harga penjualan bisa berubah-ubah, sehingga diperlukan upaya perbaikan dalam meningkatkan nilai ekonomi industri pada produk olahan susu dengan menambah inovasi dan perlu adanya penambahan biaya entertain yang efisien untuk menarik minat pembeli produk olahan. Pada Gambar 3 perbaikan model bisnis berdasarkan hasil yang telah diuraikan.

\section{KESIMPULAN}

Pemetaan kondisi awal model bisnis klaster susu Cipageran memiliki beberapa kendala dalam menjalankan model bisnisnya, yaitu: (1) terbatasnya (modal usaha, infrastruktur, mesin, SDM dan jangkauan pemasaran), (2) kurang dukungan kebijakan pemerintah mengenai perizinan, (3) belum adanya integrasi yang jelas antara kelompok peternak, kelompok pengolah susu dan tim pengurus sensucip, (4) belum adanya sistem manajemen yang mengatur dan menghubungkan ketiga komponen penting disensucip dan payung hukum yang melindungi kelompok peternak dan kelompok pengolah susu. Hal tersebut menyebabkan model bisnis yang dijalankan Sensucip selaku local champion dari klaster industri olahan susu Cipageran tidak efektif.

Teridentifikasi faktor internal dan eksternal yang menjadi kekuatan, kelemahan, peluang dan ancaman bagi klaster industri olahan susu Cipageran dalam mengembangkan model bisnisnya untuk memperbaiki model kanvas yang telah ada, melalui analisis SWOT, wawancara (depth interview), focus group discussion (FGD) dan pengamatan langsung terhadap kondisi organisasi saat ini dilihat dari kondisi faktor, struktur persaingan dan strategi perusahaan, industri pemasok, terkait dan inti, pembeli/konsumen.

Perumusan strategi melalui matriks SWOT ini menghasilkan empat strategi, yaitu: (1) Mengembangkan infrastruktur dan jaringan teknologi informasi; (2) mengembangkan SDM dari kelompok pengolah dan peternak sapi; (3) mengembangkan budaya inovasi dengan memanfaatkan hubungan kemitraan yang kuat, jiwa dan mental wirausaha yang tinggi dan mutu yang baik sesuai SOP yang berlaku; (4) meningkatkan nilai ekonomi pada klaster industri olahan susu sapi seperti kemampuan leadership dan pembuatan legalisasi kontrak antara pengolah, peternak dan konsumen. Strategi dari matriks SWOT ini menghasilkan perbaikan pada model bisnis setiap unsurnya.

\section{UCAPAN TERIMAKASIH}

Penulis mengucapkan terimakasih kepada Biro Perencanaan dan Keuangan Badan Pengkajian dan Penerapan Teknologi (BPPT) dan Pusbindiklat BPPT yang telah mendukung penelitian ini melalui Beasiswa Pusbindiklat BPPT Tahun 2015 dengan SK Nomor: SP/57/BPPT/III/2015. Ucapan terimakash juga kami ucapkan kepada Kedeputian Pusat Kebijakan Teknologi dan Tim Klaster Industri yang memberikan kesempatan untuk menyusun penelitian mengenai Klaster Industri Produk Olahan Susu Cipageran dan Ibu Rina Rosdiana SMDWP Sentra Susu Cipageran dan Pemerintah Kota Cimahi dan para responden yang telah memberikan informasi dan memfasilitasi pelaksanaan penelitian ini. 


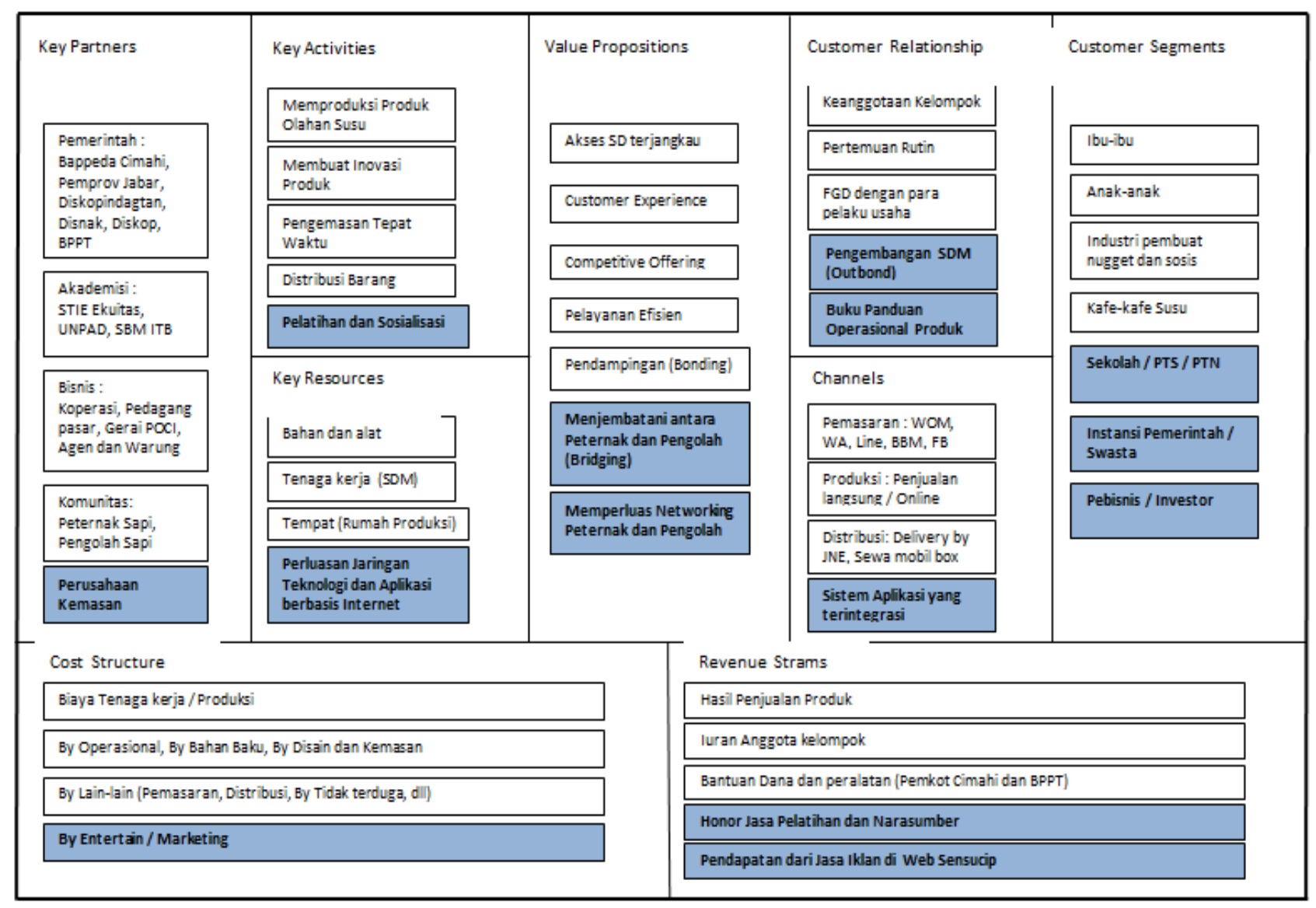

Gambar 3. Perbaikan model bisnis klaster Susu Cipageran

\section{DAFTAR PUSTAKA}

Aisyah, S.A, B. Sanim, A. Maulana. 2013. Strategi pengembangan usaha sapi potong (studi kasus pada CV Mitra Tani Farm). Jurnal Manajemen \& Agribisnis 10 (2): 109-116

Armunanto, D. 2013. Strategi pengembangan ternak sapi potong melalui kemitraan di PT.Great Giant livestock Company [Tesis].Bogor (ID): Institut Pertanian Bogor.

Awaludin, E. 2004. Strategi Pengembangan Bisnis Mikro Bank EDO. [Tesis].Bogor (ID): Institut Pertanian Bogor.

[BPPT] Badan Pengkajian dan Penerapan Teknologi. 2011. Naskah Akademik Buku Putih Penguatan Sistem Inovasi Nasional. Jakarta: Deputi Bidang Pengkajian Kebijakan Teknologi Badan Pengkajian dan Penerapan Teknologi.

[Bappeda] Badan Perencanaan Pembangunan Daerah. 2014. Survei Potensi Sosial Ekonomi Sentra Susu Sapi Cipageran Kota Cimahi, Bappeda Kota Cimahi.

Casadesus, M.R., J.E. Ricart. 2010. From strategy to business models and into tactics. Long Range Plan. 43:195-215.
Chesbrough, H. 2010. Business model innovation: opportunities and barriers. Long Range Plan. 43: 354-363

Destiani, D.P. 2014. Analisis Strategi Model Bisnis Kanvas pada PT.Angkasa Pura II untuk Bandara International Soekarno Hatta.[Tesis].Bogor (ID): Institut Pertanian Bogor.

Giesen, Edward, Riddleberger, Eric, Christner, Richard \& Bell, Ragna.2010. When and how to innovate your business model.VOL.38 No. 4.2010,pp.17-26 Emerald Group Publishing Limited.

[Kemenppa] Kementerian Pemberdayaan Perempuan dan Perlindungan Anak Republik Indonesia. 2015. Manual Model Pelaksanaan Kebijaksanaan Industri Rumahan melalui Cluster Makanan dan Minuman (Model Pengembangan Industri Rumahan Susu Sapi dan Produk Olahan Susu sapi), Cipageran Kelurahan Cipageran-Kota Cimahi.

Khusna, A. 2015. Strategi Pengembangan Agribisnis Sapi Potong di Kabupaten Bondowoso [Tesis]. Bogor (ID): Institut Pertanian Bogor. 
Osterwalder, A., Y. Pigneur. 2014. Business model generation. Jakarta (ID): PT Elex Media Komputindo.

Rosenfeld, A. Stuart. 1997. Bringing Business Clusters Into The mainstream of Economic Development.European Planning Studies. Volumes issues.

Shafer, S.M., H.J. Smith, J.C. Linder. 2005. The Power of Business Models. Business Horizons, 48(3): 199-207
Silalahi, K.A. 2014. Analisis Model Bisnis pada Divisi Agribisnis Bank Rakyat Indonesia menggunakan Pendekatan Model Bisnis Kanvas [Tesis]. Bogor (ID): Institut Pertanian Bogor

Tikkanen, H., A.I. Juha, P. Parvinen, P.K. Juha. 2005. Managerial Cognition, action and the business model of the firm management decision. International of Management, 5 (6): 102-115 